\title{
Dispute Regulation in the Institutional Development of the Asian Infrastructure Investment Bank: Establishing the Normative Legal Implications of the Belt and Road Initiative
}

\author{
Malik R. Dahlan*
}

\begin{abstract}
The regionalism versus internationalism debate has given rise to a rich discourse in international trade law. Regionalism is viewed either as a way to promote international integration, or to protect regions and thus against the multilateral spirit that characterizes a truly global organization. This debate is explored in international financial law and international financial institutions therein, with the Asian Infrastructure Investment Bank (АІІВ) and New Development Bank as examples. This chapter suggests that 'principled' dispute regulation, having an intellectual anchor in 'multilevel governance', provides a new dimension to underpin regional governance. Exploring China's Belt and Road Initiative (BRI) has the potential to redefine multilevel trade governance and the laws that establish its order. As a result, new 'Eastern' international legal norms are emerging. A new international trade and investment order will necessarily lead to disagreements over its interpretation. However, existing dispute resolution mechanisms may not work effectively. In order to overcome this practical challenge, this chapter examines some important legal aspects of the BRI and offers a new concept of dispute regulation. For the central argument, mediation will be specifically analyzed to inform a new AIIB paradigm. The chapter intends to begin a discussion of some emerging trends in international trade and relevant rules, in the context of the AIIB.
\end{abstract}

* Malik R. Dahlan, professor of International Law and Public Policy, Centre for Commercial Law Studies (CCLS), Queen Mary, University of London (QMUL), malik.dahlan@quraysh. com. I would like to acknowledge the support of my research assistant, Yajie Gao, CCLS PhD candidate and her translation contributions to this paper.

(C) ASIAN INFRASTRUCTURE INVESTMENT BANK (AIIB), 2019 | DOI:10.1163/9789004407411_010 
Since its promulgation by President Xi Jinping in 2013, the Belt and Road Initiative (BRI) has attracted attention both in China and abroad. As it stands, the BRI is an economic proposal whose implementation requires cultural integration and legal protection of participating countries (Participating States). Among the more than 65 Participating States, ${ }^{1}$ some are common law countries, some are continental civil law countries, while most of the Middle East belong to Islamic and hybrid legal traditions. Due to differences in political, economic and cultural environment, economic and trade disputes between stakeholders cannot be circumvented. To underline the inevitability of disputes, we refer to the Hambantota deep-water port project as an example. ${ }^{2}$ This joint project between China and Sri Lanka became infamously well-known when it nearly collapsed following Sri Lanka's failure to repay a sizable loan to China. The China Merchants Port Holdings Company Limited had to ultimately intervene to rescue the venture, obtaining management rights over the project for 99 years. This intervention has prompted objections from both the local communities and Sri Lankan politicians, which cast a shadow of uncertainty over the project, the perception of BRI projects and resultant disputes.

Generally speaking, disputes could arise in three ways, namely commercial disputes, international trade disputes, and investment disputes. ${ }^{3}$ In the meantime, challenges that come with resolutions to these modes of disputes are ever increasing. Time-consuming processes, lack of transparency, dangers to state sovereignty and high costs are exhibited in international commercial arbitration, the dispute resolution mechanism of the World Trade Organization (WTO) and Investor-State Dispute Settlement (ISDS). ${ }^{4}$ Effective enforcement of arbitral awards is another obstacle relevant parties have to manage in practice. ${ }^{5}$ Be that as it may, the added value of ISDS is manifold. In the past, investors seeking to obtain remedies had to lobby their governments into negotiating the dispute at state-to-state level. The establishment of ISDs has helped

Xinhua Silk Road Information Service, 25 December 2017.

Sirilal, 20 June 2018.

3 G Wang 2017.

4 ISDS is a procedural mechanism provided for in international agreements on investment. ISDS allows an investor from one country to bring a case directly against the country in which they have invested before an arbitration tribunal. To bring a case, an investor must claim that the other Party has breached rules set out in the agreement. See European Commission, 'Factsheet', 3 October 2013.

5 Some countries along the Belt and Road (B\&R) are not contracting party of the Convention on the Recognition and Enforcement of Foreign Arbitral Awards (New York Convention). 
to avoid this politicization of conflicts, and the growth of foreign investment has been promoted by the establishment of ISDS as an adequate neutral dispute resolution system. When it comes to international trade disputes, the applicable rules of the wто provide the compass in most cases. However, Wто rules cannot fully resolve disputes between and within the Participating States of the BRI, especially when many countries hosting BRI projects are not members of the พтоо. ${ }^{6}$ As for international commercial disputes, parties usually prefer arbitration over adjudication. ${ }^{7}$

In terms of enforcement, among all the Participating States of the BRI, more than $5^{0}$ are contracting parties of the Convention on the Recognition and Enforcement of Foreign Arbitral Awards (New York Convention), the prominent mechanism for the recognition and enforcement of commercial arbitral awards. However, only fewer than 20 countries $^{8}$ have signed civil and criminal judicial assistance treaties with China. When investment disputes arise as a result of infrastructure projects, a priority of the BRI, the political, economic and business landscape is usually both fluid and complex. Furthermore, in accordance with the 'World Investment Report 2018: Investment and New Industrial Policies', six out of the 12 most frequent respondent States between 1987 and 2017 are along the Belt and Road (B\&R) (the Czech Republic, 35; Egypt, 31; Poland, 26; India, 24; the Russian Federation, 24 and the Ukraine, 22). ${ }^{9}$ In many cases, softer measures and diplomatic means, such as negotiation and mediation, could be tried in the first place, taking into consideration the eastern legal and cultural traditions. Nevertheless, a modified ISDS mechanism might still be the first and ultimate choice of relevant parties, which will be further discussed in later sections of this paper.

In most cases, ISDS provisions could be found in bilateral investment treaties (BITs) or free trade agreements (FTAs). To date, China is yet to sign investment agreements with 12 of the countries along the $B \& R .{ }^{10}$ For all of the more than 30 BITs China has already signed with countries along the B\&R, the ISDS

6 For example, Turkmenistan, Uzbekistan, Afghanistan, Azerbaijan, Bahrain, Iran, Iraq, Lebanon and Syria are not member states of the wTo.

7 Queen Mary University of London and White \& Cass 2015.

8 Xiang, 'List of Civil and Criminal Treaties', 8 December 2017; see also, Xiang, 'List of Civil, Commercial and Criminal Treaties', 8 December 2017; for more updated information, see the Treaty Database of the PRC <http://treaty.mfa.gov.cn/Treaty/web/index.jsp> accessed 28 January 2019.

$9 \quad$ United Nations Conference on Trade and Development 2018.

10 The 12 countries include East Timor, Bangladesh, Afghanistan, Nepal, Maldives, the Kingdom of Bhutan, Iraq, Jordan, Pakistan, Latvia, Bosnia and Herzegovina and the Republic of Montenegro. 
provision is only applicable to disputes regarding the amount of expropriation compensation..$^{11}$ As a result, investor-State (IS) arbitration mechanisms are not applicable when the host country violates other provisions of international investment agreements, such as obligations required by principles of fair and equitable treatment and national treatment. In the past, China was the host country under most circumstances. At present, however, a growing number of Chinese investors are shifting their focus towards overseas markets, especially against the backdrop of the BRI.

In the following sections of the chapter, Section 2 will introduce both the BRI and the Asian Infrastructure Investment Bank (AIIB) and will explore their relationship and areas of intersectionality. Against the backdrop of the BRI and institutional legal foundations of the AIIB, Section 3 will explore the urgent need for a new Asian dispute resolution model, and more specifically through mediation. In keeping with 'multilevel governance' we go on to propose to establish a permanent dispute resolution registry affiliated with the AIIB. Section 4 lays down recommendations for the regulation of disputes to make such a registry optimally attractive. This is completed with the conclusion.

\section{2 \\ The Belt and Road Initiative and the Asian Infrastructure Investment Bank}

This section will look at, (i) the BRI, on the one hand, and (ii) the AIIB on the other, before (iii) considering the interrelationship between the two.

\subsection{The Belt and Road Initiative}

President Xi Jinping originally laid out the concept of $\mathrm{BRI}^{12}$ during his first visit to Central and Southeast Asia in 2013. On 28 March 2015, the National

11 The more than 30 countries include some of the most important host countries for Chinese investors, such as the People's Republic of Mongolia, the United Arab Emirates, Turkey and Kazakhstan.

12 There has been some political controversy internationally critical of the BRI. President Xi Jinping and central departments of the PRC seem to have defensively contributed to the debate at least in two rebuttals: $a$ ) The BRI as China's version of the 'Marshall Plan'? China's official response is that, 'The BRI is not China's conspiracy as commented by somebody. It does not like the "Marshall Plan" put forward after the World War II, nor a plot. Even if China is after something, it would be to meet interests of all through consultation and joint effort, to put policy communication, infrastructure interconnection, free trade, fund liquidity and mutual understanding between peoples into practice, so as to establish a new platform for international cooperation, infuse momentum to common development, and make the BRI benefit more countries and larger scale of people'. (President Xi's 
Development and Reform Commission (NDRC), the Ministry of Foreign Affairs, together with the Ministry of Commerce (Моғсом) published the 'Vision and Action to Promote the Co-Construction of a "Silk Road Economic Belt" and a '21st-Century Maritime Silk Road' under the authority of the State Council (B\&R Document). ${ }^{13}$ Building on the mystique and history of the ancient Silk Road and its symbolic role as a connection between different cultures, the BRI aims to develop economic cooperation and partnerships with countries along the B\&R. The overarching aim is to establish an 'interest', 'destiny' and 'liability' community through existing bilateral or multilateral mechanisms and regional cooperation platforms.

To the best of our knowledge, there has been neither a national nor international established legal instrument indicating the legal nature of the BRI. One can trace some declaratory origins in the B\&R Document and working report presented at the 19th National People's Congress and series of related speeches delivered by Chinese authorities under various occasions. The B\&R Document is best seen as a kind of guiding brand with a potential to be soft law if indeed the BRI becomes distinguishable from the PRC's slogans. ${ }^{14}$ The B\&R Document could also be regarded as a statement of policy, a strategic orientation or a form of proclamation. ${ }^{15}$

\subsection{The Asian Infrastructure Investment Bank}

The proposal to establish the Asian Infrastructure Investment Bank (AIIB) came against the backdrop of Multilateral Development Banks (MDB) failure to reform and the increasing need for more investment in infrastructure. ${ }^{16}$ Overall, the legal purpose of the АІІв is to ${ }^{17}$

Statement in his meeting with the current Chairman and the Chairman to be of the Boao Forum for Asia, see Xinhua Net, 11 April 2018) and; $b$ ) The BRI is China's geopolitical tools? China's official response, 'China is always ready to share development experience with other countries and regions, and would never interfere with internal politics of others, export social system and development model, nor force any other countries or regions to do anything. What the establishment of the BRI is seeking is an innovative model of winwin through cooperation, instead of old geopolitical ways. What China is trying to do is not setting up relatively smaller community which would bring side effect to stability, but to form a huge harmonious and inclusive "family"'. (Xi, 14 May 2017). Belt and Road Portal, 'Common Misunderstandings of the BRI'. NDRC, MFA and MOFCOM 2015 .

14 'Soft law' refers to a quasi-legal instrument that doesn't carry any legally binding force, or whose legally binding force is weaker than that of traditional laws and regulations.

15 Zeng 2016.

16 See, e.g., М в в Working Group on Infrastructure 2011.

17 AІІв Articles of Agreement (AOA), art 1. 
(i) foster sustainable economic development, create wealth and improve infrastructure connectivity in Asia by investing in infrastructure and other productive sectors; and (ii) promote regional cooperation and partnership in addressing development challenges by working in close collaboration with other multilateral and bilateral development institutions.

Some comment that the limited governance reform of the International Monetary Fund and the World Bank were not enough for China and other developing countries' shares to keep up with their growing ranking in the global economy. ${ }^{18}$ Furthermore, China's turn to the M DB could be explained by making use of advantages of multilateral leverage and efficiency ${ }^{19}$ and avoiding disadvantages of bilateral approaches, such as higher cost and public relations risks. $^{20}$

Since the commencement of its operation in January 2016, the АІІв has promulgated several instruments and constitutive documents and has filled out its governance structure. It intends to act as an $\mathrm{MDB}$, enjoying similar capacities with institutions such as the World Bank, the European Bank for Reconstruction and Development and the Development Bank of Latin America, while keeping its own distinct focus. The АІІв currently has 87 approved members $^{21}$ and is open to additional applicants. By 2015, both the United Kingdom and France had joined, to the dismay of the United States, which issued warnings about 'a trend of constant accommodation' towards China and expressed the hope that the UK would push for higher standards. ${ }^{22}$ On 23 March 2017, the AIIB announced that it had approved 13 new applicants, including Canada, a major ally of the US. ${ }^{23}$ The newly-founded МDв has already obtained tripleA ratings from the world's top credit rating institutions: Moody's, Fitch and Standard and Poor's. ${ }^{24}$

The AIIB's governance structure inherited much from traditional MDBs, just as each MDв has been built on the foundations of its predecessors, while still bearing specific innovative attributes in relation to its function and mission. Like other MDBs, the AIIB's governance hierarchy, explained in the Articles of Agreement, has three levels: Board of Governors, Board of Directors and the President. The power to approve arrangements for cooperation with other

\footnotetext{
18 Duran 2018.

19 Morris 2016.

20 Lichtenstein, A Comparative Guide to the AIIB 2018.

21 АIIB, 'Members'.

22 Watt, Lewis and Branigan, 13 March 2015.

23 Qiu and Beijing Monitoring Desk, 23 March 2017.

24 AIIB, 'Third Triple-A Credit Rating', 18 July 2017.
} 
international organizations is generally retained by the Board of Governors in other MDBs. As for the АІІв, however, it is directly assigned to the Board of Directors. The Board of Directors' non-resident status, expanded powers of delegation and corresponding supervision mechanism is unique to the АІІв. ${ }^{25}$ With respect to the presidency, the selection of the President and VicePresident through an open, transparent and merit-based process sets an innovative legal standard. ${ }^{26}$ In this context, it is important to note that the AIIB Articles of Agreement does not designate nor establish a dispute resolution organ as few constituent instruments do so.

As for financial support to infrastructure projects, the AIIB considers three criteria before providing such facility: (i) whether the project is financially sustainable and could generate stable revenue; (ii) whether it is environmentally-friendly; and (iii) whether it is accepted by the local communities. ${ }^{27}$ Until 30 December 2018, the AIIB has provided loans to support 34 projects, ${ }^{28}$ all of which are located in Asia and neighboring developing countries. The projects tend to focus on, among other things, slum renovation, flood prevention, natural gas pipeline construction, expressways and backroads, broadband networks, electric power systems and other core infrastructure development projects.

\subsection{The Relationship between the BRI and the AIIB}

President Xi Jinping announced the ambition set up the AIIB in October 2013 when he met president of Indonesia, Susilo Bambang Yudhoyono, for the first time, so as to promote interconnectivity and economic integration in the region. ${ }^{29}$ In this spirit, the Chinese President has delineated a vision that would encourage the much-needed maximization of regional cooperation, trade and synergy, ${ }^{30}$ as well as advance socialization, interdependence, interconnectedness, regional growth and development. From a strategic perspective, we argue that the AIIB is a crucial component of the BRI, which is essential for the vision's success and instrumental for its practical advancement. Furthermore, one could see the relationship between the AIIB and BRI from the following four perspectives.

\footnotetext{
25 Lichtenstein, 'Governance of the AIIB' 2018, 56-64.

26 AIIB AOA, arts 29(1) and 30(1).

27 Jin, 16 January 2018. Detailed requirements for all of the AIIB's investment operations, please see АІІв, 'Operational Policy on Financing' 2016 (updated 2017).

28 АІІв, 'Approved Projects'.

29 Xinhua, 'China proposes an Asian infrastructure investment bank', 3 October 2013.

30 Economic Information Daily, 22 May 2014.
} 
Firstly, the AIIB has already developed into the second largest multilateral development institution after the World Bank in terms of membership of borrowing countries while the BRI is China driven. Nonetheless, there is great overlap between countries along the B\&R and membership of АІІв. ${ }^{31}$ Second, the vision of the AIIB is to accelerate the development of Asian infrastructure and to set up a financing platform, which will help promote the integration of the regional economy. This approach is consistent with and complementary to that of the BRI. ${ }^{32}$ Third, the АIIв can provide financial support to the BRI. The AIIB was not established specifically to fund BRI schemes. Nevertheless, as long as a project approved by the BRI corresponds with the AIIB's investment principles, the АІІв would always be ready to provide loans. ${ }^{33}$ Regionally speaking, capital outflow has long been the main threat to Asian economic security. By providing high quality financial services, the AIIB could not only help meet the enormous financial requirements of the BRI, but also upgrade the capital utilization rate of Asian countries and attract global capital to the region. Fourth, the АІІв would facilitate the establishment of a complete 'financial chain' for the BRI. The AIIB could not only help transform the traditional East Asian preference for 'safe' deposits over 'risky' investment, ${ }^{34}$ but also refocus the public business and investment attention from the virtual economy back to the real economy. Together with China's sovereign wealth fund, the Silk Road Fund, the AIIB is able to employ and procure various financial instruments in order to maximize the effectiveness of its capital.

\section{3}

Dispute Resolution Mechanism

In this section, various aspects of a dispute resolution mechanism related to the BRI and AIIB are contemplated by arguing, (i) for the urgent need for a grand Asian dispute resolution mechanism, and (ii) that alternative dispute resolution (ADR), particularly mediation, is the key, before (iii) looking specifically at the increasing importance of mediation, as well as (iv) dispute boards, and lastly by (v) contemplating the potential of reforms carried on to China's dispute resolution governance.

\footnotetext{
31 AIIB AOA, arts 1, 2 and 3.

32 AIIB AOA, art 1.

33 Belt and Road Portal, 'Achievement Made by the AII в Makes the Chinese Proud', 17 January 2018.

34 For example, Zhang and others 2018.
} 


\subsection{The Urgent Need for a Grand Asian Dispute Resolution Mechanism}

With the utilization of the BRI, China declared that it seeks to advance greater peace, stability, joint progress and prosperity. But, as we know, there are always challenges associated with grand policy and sweeping transformations, especially when dealing with colossal investments or co-investments concerning critical national infrastructures such as ports, airports, railways, pipelines and energy generation and distribution. In this respect, while recognizing the Chinese Vision's commitment to and pursuit of harmony, ${ }^{35}$ it is necessary to include a clear and independent resolution system, such as ISDS provisions and ADR including mediation and dispute boards within China's model. Harmony is an idea and an ideal legal norm. Dispute resolution is perhaps to realize law and harmony it in the real world. Accordingly, the following four observations can be made.

Firstly, civil and business judicial assistance and cooperation between countries along the B\&R has not been put in place. To take China as an example, among the more than 65 Participating States of the B\&R, less than 20 countries have signed civil (commercial) judicial assistance treaties with China. ${ }^{36}$ In other words, domestic judgements or decisions, will neither be recognized nor enforced in other $\mathrm{B} \& \mathrm{R}$ countries under most circumstances.

Second, to date, there is no multilateral dispute resolution mechanism in place which could effectively resolve most of the disputes arising between countries along the B\&R. As for bilateral agreements, due to extensive differences in the substance of bilateral agreements, there is no effective or unified dispute resolution (and enforcement) mechanism in place. When a dispute arises, other disagreements will also arise, such as what substantive and procedural law shall be applied.

Thirdly, international judicial bodies are witnessing interesting and evolving relationships with other courts and tribunals, which provides interesting grounds for argumentation. For example, in March 2018, the Court of Justice of the European Union (CJEU) ruled that ISDS contained in the Bilateral Investment Treaty (ВIт) between Netherland and the Czech and Slovak 'has an adverse effect on the autonomy of EU law' and is therefore 'not in principle

35 NDRC, MFA and MOFCOM 2015, pt 2:

The Initiative is harmonious and inclusive. It advocates tolerance among civilizations, respects the paths and modes of development chosen by different countries, and supports dialogues among different civilizations on the principles of seeking common ground while shelving differences and drawing on each other's strengths, so that all countries can coexist in peace for common prosperity. 
incompatible with EU law'. ${ }^{37}$ The judgement contrasts with the European Commission's opposing attitude towards investor-State arbitration under the current intra-EU в ITs, which has been working to establish a Multilateral Investment Court, with the aim of replacing the dispute settlement provisions in the old investment agreements. ${ }^{38}$

Another more political example is US President Donald Trump's threat to withdraw the US from the wTо, with US Trade Representative, Robert Lighthizer, accusing the wто dispute-settlement system of interfering with US sovereignty, particularly on anti-dumping cases. ${ }^{39}$ Moreover, in June 2018, the US again blocked the appointments to existing Appellate Body vacancies. ${ }^{40}$ Furthermore, the so-called 'trade war' between the US and China in 2018 also pushes the wTo Appellate Body and dispute settlement system to the eye of the storm. ${ }^{41}$

Fourthly, Participating States of the BRI institutionalize and explain international rules differently. Normative and practical approaches to the legal and regulatory frameworks are often divergent and mismatched. Therefore, it becomes clear that current dispute resolution mechanisms cannot match the distinct development and nature of the BRI and its diverse composition. We also note that given the nature of the BRI and the predominant cultural and sociopolitical characteristics of the Chinese system, any approach that does not have soft dispute resolution mechanisms, such as mediation or dispute boards, at its core will be problematic.

The absence of an institutionally established dispute resolution system, soft or hard, will be problematic in the long run for the overall success of the BRI and its underlying raison dêtre. Without a perceived neutral means to resolve disputes, any action taken by Chinese authorities to deal with disputes will be seen as arbitrary with political and diplomatic ramifications, as seen in the case of Sri Lanka.

\section{2 $\quad$ ADR Is the Key}

Disputes could be resolved either by litigation or alternative dispute resolution mechanism, such as arbitration, conciliation and mediation. Mediation, especially in the case of the BRI, may give legal determinacy to the concept of harmony and avoid bureaucratic and legal burdens. The objective of mediation in

CJEU, Slowakische Republikv Achmea BV 2018.

38 European Commission, 'The Multilateral Investment Court Project', 21 December 2016.

39 Micklethwait, Talev and Jacobs, 30 August 2018.

$40 \quad$ WTO, 22 June 2018.

41 For example, Petersmann 2018. 
particular is to make interest-based and future-oriented recommendations so as to create possibilities beyond legal remedies. Even though the agreements must rest on a solid dispute resolution framework, the optimal solutions will most likely arise through the prioritization of a tailored mediation mechanism within the distinct BRI ADR structure. Mediation is a 'party-centreed' consensual facilitation process that through an unbiased neutral helps two sides find an optimal settlement. As highlighted, it's strength lies in the process being confidential, without prejudice and unbiased, and the parties resorting to mediation maintain self-determination rather than having a decision imposed on them by a judge or tribunal, removing the suspicion of political interference.

Investor-State mediation is increasingly becoming an accepted method for resolving Investor State disputes and a real path for conflicting parties with different agendas but intending to maintain their investment and trade relationship. Mediation tend to be a preferred choice when both parties wish to maintain control over the outcome of the dispute resolution; the monetary costs of pursuing litigation or arbitration are too high in comparison with what a party can expect to recover by a decision in its favor; a fast resolution is of the utmost importance; maintaining a relationship is more important than the substantive outcome; or neither side is certain that it would prevail in litigation or arbitration.

Be that as it may, the Centre for Effective Dispute Resolution (CEDR $)^{42}$ has also pointed to the absence of deep personal hostility, distrust between the parties and the party's requirement for non-monetary relief, such as an apology, a public statement or acknowledgment to third parties. In general, the International Centre for Settlement of Investment Disputes (ICSID) and CEDR share more similar outlooks in this regard. In comparison, the Energy Charter Treaty (ЕСT) also mentioned another two criteria, namely (i) parties do not just seek quantum or a specific technical issue as remedies but are looking for broader settlement options; and (ii) matters of fundamental principle are not at stake. Furthermore, during the cooling-off period, structured negotiation and good offices are most popular among relevant parties, on the basis of feedback from the ICSID and the ЕСT. In other words, mediation permits all relevant stakeholders to participate in the process leading to issues being more broadly addressed and more coherent settlements to emerge. This of course is critical in diplomacy and the transactional relations where States are involved.

42 The content of subsection 3.2. is based on survey feedback of one working staff from each of the International Centre for Settlement of Investment Disputes, the Energy Charter Treaty and the CEDR on China and BRI Dispute resolution. It is a limited scope of personal views and experiences of the staff members. 


\subsection{The Increasingly Important Role Played by Mediation}

Despite some disadvantages ${ }^{43}$ mediation continues to acquire increasing popularity in practice. In recent years, various international institutions all over the world have taken substantive actions to make mediation a more proactive way to resolve disputes, especially IS dispute. To be more specific, the 'IBA Rules on Investor-State Mediation'44 provide a legal framework specifically designed for mediation in the IS context, offering a helpful starting point for parties interested in pursuing investment mediation..$^{45}$ Mediation has also been included in recent free trade and investment agreement, such as the EUCanada Comprehensive Economic and Trade Agreement, Trans-Pacific Partnership and features in some BITs. ${ }^{46}$

The ЕСт is a classic example of encouraging mediation in ISDS. In July 2016, the 'Guide on Investment Mediation' (Guide) was approved. ${ }^{47}$ The aim of the Guide is to provide an explanatory document/template that could be voluntarily used by governments and companies to take the decision on whether to go for mediation and how to prepare for it. The Guide creates a system on conflict management to complement States' internal approaches to facilitate an assessment on whether to opt for mediation in the first place. ICSID has also embraced mediation as part of its dispute resolution process, recognizing that its traditional conciliation process too closely mirrors arbitration and that a more pragmatic approach, furthered by mediation is needed. ${ }^{48}$

\subsection{Dispute Boards}

It is worth mentioning in the context of ADR regulation mechanisms that could effectively be employed in the BRI, in addition to mediation, dispute boards (Boards). These Boards have been used extensively for large infrastructure and construction projects for many years. In particular, all World Bank projects using the International Federation of Consulting Engineers (FIDIC) form of construction contract will in most cases require a dispute board. These Boards are typically made up of one to three neutrals depending on the size of the project. The stated aim of these Boards is to accompany the project from beginning

43 For example, because of the characteristic of confidentiality, recording relevant mediation precedents is difficult. Due to political realities, mandated authorities usually lack proactive will to take ownership over the settlement. IBA, IBA Rules for Investor-State Mediation 2012.

45 ICSID, 'Investor-State Mediation'.

46 For example, the Thailand Bilateral Investment Treaties.

47 Energy Charter Secretariat 2016.

48 ICSID has joined the ECT and CEDR in running mediation programs for IS Mediators recognizing that special knowledge and skills are needed for mediation in the ISDS context. 
to end, thus coming to have an intimate knowledge of the project objectives, progress and issues, as well as getting to know the parties. Being imbedded in the project the board is very effective in dealing with issues arising at an early stage and through non-binding guidance or if desired interim binding decision nips disputes in the bud. Again, forms of facilitated negotiation or mediation are employed to get the parties to buy in to any settlement reached. Given the nature and size of many BRI projects, Dispute Boards should be encouraged.

\subsection{Essential Chinese Official Documentation and Judicial Interpretation}

Mediation is an important dispute resolution method, reflected in the traditional Asian culture of mutual understanding, mutual accommodation and harmony, recognized by both domestic and overseas judicial circles. ${ }^{49}$ The Supreme People's Court (SPC) has, and presumably will continue to, put great emphasis on promoting the development of mediation, including 'Opinions of the SPC on Further Deepening the Reform of the Diversified Dispute Resolution Mechanism of the People's Courts' and 'Provisions of the SPC on Invited Mediation by the People's Courts' promulgated in June 2016.

On 23 January 2018, the Second Conference of the Central 'All-round and Deep Reform Leading Team' (Conference) was held in Beijing. President Xi Jinping delivered the keynote speech. The Conference deliberated and approved the 'Opinions on Establishing the BRI Dispute Resolution Mechanism and Institute' (Opinions)..$^{50}$ They proposed the establishment of the BRI Dispute Resolution Mechanism and Institute under the principle of achieving shared growth through cooperation and dialogue. In accordance with the Opinions, the SPC would establish international commercial courts in Beijing, Xi'an and Shenzhen respectively. The court located in Xi'an will face the 'silk economic belt', while that in Shenzhen will face the 'maritime silk road'. As for the court in Beijing, it will act as the headquarter in this regard.

In accordance with the existing Chinese judicial, arbitral and mediation institutes, the new BRI structure will absorb and integrate legal services, structures and resources from both domestic and international sources. The aim of the Opinions is to establish a broad, diversified and all-inclusive mechanism that efficiently connects litigation, arbitration and mediation. The new mechanism and the corresponding institute aim to properly settle trade and investment disputes arising from the BRI. Such disputes resolution processes will be advanced in accordance with the established laws and regulations with a view

49 See Lee and Teh (eds), An Asian Perspective on Mediation 2009.

50 Xinhua, 'Opinions on BRI Dispute Resolution', 24 January 2018. 
to equally protect rights and interests of both domestic and foreign parties, so as to establish a stable, fair and transparent business environment.

In response to the Opinions, the SPC enacted the 'Provisions on Several Issues Concerning the Establishment of International Commercial Courts' (Provisions) on 25 June 2018. Article 1 of the Provisions makes it clear that the international commercial courts to be established are permanent judicial institutes affiliated with the SPC. The Provisions only apply to trade and investment disputes between private parties, excluding those between States or the investor and the host State. In order to set up a 'one-stop-shop' international commercial dispute resolution mechanism effectively connecting mediation, arbitration and litigation, the SPC establishes International Commercial Expert Commission (ICEC), ${ }^{51}$ and selects qualified international commercial mediation institutions, commercial arbitration institutions and commercial courts.

The Provisions pay considerable attention to the role played by mediation in international commercial dispute resolution, and explicitly support domestic qualified mediation institutions with high international reputations to mediate BRI-related disputes. Guidance with respect to commencement, mediation agreement or related verdict, as well as enforceability of mediation agreement are also provided.

On 5 December 2018, the SPC released three regulatory documents, naming the 'Notice of the Office of the SPC on Introducing the First Batch of International Commercial Arbitration and Mediation Institutes to the 'One-StopShop' International Commercial Dispute Multilateral Resolution Mechanism' (Notice on Introducing the First Batch of International Commercial Arbitration and Mediation Institutes), the 'Trial Procedure Rules of the International Commercial Courts of the SPC' (Trial Procedure Rules) and the 'Trial Working Rules of the ICEC of the International Commercial Courts of the SPC' (Trial Working Rules of the ICEC), ${ }^{52}$ which are essential matching documents for the Provisions, marking the phased achievement that has already been made by the SPC in implementing the Opinions. The implementation of the three documents means that the one-stop-shop international commercial multilateral dispute resolution platform has been officially set up and entered the operational phase.

As for the 'Notice on Introducing the First Batch of International Commercial Arbitration and Mediation Institutes', five international commercial arbitration institutes and two international commercial mediation institutes

$5^{1}$ SPC, Decision on the Establishment of ICEC 2018.

52 SPC, 'The SPC Releases Matching Documents', 5 December 2018. 
have been assigned to provide an institutional guarantee for the international commercial multilateral dispute resolution mechanism. The 'Trial Procedure Rules' provide guidance for working procedures of the international commercial courts, including case acceptance, delivery, pre-trial mediation, case hearing, enforcement, support for arbitration and others, making clear the connection between litigation and mediation, as well as litigation and arbitration, which plays a pivotal role in directing relevant parties both home and abroad to choose dispute resolutions independently through the one-stopshop mechanism, and having international commercial disputes resolved fairly and efficiently. The 'Trial Working Rules of the ICEC' provide more detailed rules pertaining to function and composition of the ICEC, qualification conditions, duties and obligations of the expert commissioner, duties of the expert commission office, expert commissioner mediation and consultation mechanism, function guarantee for the expert commissioner and others.

\section{$4 \quad$ A Proposal for Regulating Disputes}

When it comes to how to establish a dispute settlement mechanism that could fully fit the implementation of the BRI, we shall argue that certain principles must be adhered to, including procedural justice, party self-determination, the neutrality of the person or institution in charge of the resolution, equal treatment of all parties and protection-guarantees of the full and free participation by all parties in the process.

It is to be observed that countries along the B\&R exhibit significant diversity: different geo-economic, geopolitical and geostrategic agendas; national legal environments vary and States are signatories to diverse international legal treaties, groups and trading blocs; religious backgrounds, traditions and ethno-cultural compositions differ; as well as economic systems and standings; and some of the $B \& R$ countries have endured armed conflicts for many years, leaving behind traumas, painful collective memories and a degree of fragility which raises both internal and external security concerns. In light of this complexity and series of sensitivities and delicate imbalances, new requirements focusing on the investment and the life cycle of a dispute are to be put forward for a practical and credible dispute resolution mechanism in relation to the BRI dynamic.

The goal of the BRI at its early stages is to focus on infrastructure development ${ }^{53}$ in the sphere of transport and energy infrastructures; the middle-term 
target is the establishment of a relatively mature free trade area. The potential investment and trade system that will result from the BRI may be different from traditional trade agreements, which focus on market entry and preferential treatment. It will place greater emphasis on a new economic cooperation framework aimed at being simultaneously more diverse, open and inclusive. It will be a wide-ranging system that goes beyond elimination of tariffs and includes strategic co-investments, long-term economic partnerships, pivotal energy agreements, crucial synergies and platforms for joint investments in industries such as information and communication technology.

The previous sections have highlighted the value of mediation within the demanding sphere of ISDS and, especially, in the sui generis case of the BRI. It suggests some tangible policy steps that may help establish an efficient dispute resolution mechanism in the BRI context. This is not an attempt to re-invent the wheel. Instead, the argument here is to employ best practices and make full use of existing international multilateral tools and mechanisms, while at the same time taking specific characteristics of the BRI into account. A smart adaptation and incorporation of the ISDS system could be at the core of the BRI, the AIIB, and the legal norms that could define both.

The proposal for 'principled' dispute regulation provides a new dimension to underpin the current regional versus global governance debate in international trade law as well as financial and banking law, ${ }^{54}$ within a 'multilayered governance' theory developed by Ernst-Ulrich Petersmann, Thomas Cottier among others. ${ }^{55}$ To be more specific, multilayered governance is about horizontal and vertical checks and balances. Within the overall constitutional norms, different layers of governance serve different functions, while sharing common elements of legitimacy-outcome, the rule of law and representation (together, democracy). The three sources of legitimacy are of equal importance, which means that one cannot be vital at the expense of the others. ${ }^{56}$ In terms of the regulation of disputes within negotiation theory, negotiation is one method for parties to reach possible resolutions directly with each other, involving three neutral constructs, ${ }^{57}$ naming interested-based (mediation), rights-based (court system and arbitration) and power-based (such as labor strike). ${ }^{58}$

54 Duran 2018; Hirschman 1990.

55 Joerges and Petersmann 2007.

$5^{6} \quad$ Ibid $64-67$.

57 Shamir and Kutner 2003.

$5^{8} \quad$ Ury, Brett and Goldberg 1993. 


\subsection{A Unified Dispute Resolution Mechanism Is Optimal}

Compared with mechanisms such as the WTо and the North American Free Trade Agreement, which provide different resolution methods, a unified approach is not only much easier to manage, but also would reduce litigation costs and facilitate implementation. Furthermore, a very light appeal mechanism would be optimally positioned to protect the rights and interests of relevant parties.

In the case of the BRI, a permanent dispute resolution registry is recommended to regulate the life cycle of the dispute and focus on the bigger picture of the investment. It could be a centre that emerged from and was affiliated with the AIIB (the Centre), as is ICSID with the World Bank, thereby guaranteeing international standards. The Centre could also resolve disputes between countries, in addition to a country and a foreign investor. In other words, it would be mandated to deal with international commercial, investment and trade disputes. The Centre could in addition assist in the establishment and coordination of dispute boards in conjunction with institutions such as FIDIC, International Chamber of Commerce, and the Dispute Resolution Board Foundation (DRBF).

At its inception, the panels and appellate process could be set up, while gradually developing a series of targeted tribunals, including maritime, environment, intellectual property rights and even a financial tribunal.59 As for qualification of the subject, it could be the authorities, funds, businesses or individuals from all Participating States. Facilitation arrangements could also be considered if only one of the parties is from a member State of the Centre.

As it stands, the Centre is mostly aspirational, as it is an established implied power of international organization organs to establish judicial bodies in furtherance of their mandates. The Articles of Agreement of the AIIB only mentions arbitration as a remedy for disagreements between the AIIB and a State which has ceased to be a member, or between the АІІв and any member after adoption of a resolution to terminate the operations of the Bank. ${ }^{60}$ Dispute resolution clauses could be established in a contract to utilize the international

59 To name the Asian Development Bank (ADB) as an example, 'supported thematic interventions, such as creation of a green bench for administration of environmental justice, a gender court for resolution of disputes related to gender-based violence and access to justice for urban poor'. The Paper (Nagpal 2018) concludes that 'thematic and targeted interventions have proved to be more effective than broader interventions in the justice sector'. 
dispute resolution registry, the administrative body of the Centre, headed by a registrar. State consent and public international law could also constitute the basis for creation of a dispute resolution body.

The AIIB is a young international financial institution, established only less than three years ago. It is perhaps too ambitious to set up a Centre affiliated with the AIIB in short term, considering that ICSID was established more than 20 years after the World Bank by through the Executive Directors to further the World Bank's objective of promoting international investment. Nevertheless, since ICSID has operated for more than 60 years and achieved worldwide recognition, it could still act as the very benchmark for the Centre. The main distinction between the ICSID and the Centre is that the Centre is advised to be equipped with soft yet broader regulatory competence, authorized to resolve trade, IS and commercial disputes. ${ }^{61}$ It should also function as a registry for other ADR providers the AIIB may approved. The AIIB has no plan in the medium term to establish a Centre despite the theme of the second annual AIIB Legal Conference in 2018 ('International Organizations and the Promotion of Effective Dispute Resolution'). Any such plans will depend on the practical requirement and consent of member States of the AIIB. This leads to the premise of the following section, on what are the incentives to create the Centre.

\subsection{Making a 'Centre for Dispute Regulation' Attractive}

Taking into consideration the complicated geopolitics of the vectors addressed by the BRI and the region of operations of the АIIB, a dispute resolution mechanism with a high institutional judicial structure at an early stage is hard to achieve. Making consultation a pre-condition, in regulating the life cycle of the dispute, would not only help maintain a good relationship between the parties and their investments, but also provide a window of opportunity for parties to resolve their conflicts and disputes to the greatest possible extent through an amicable, transparent process. Following these amicable negotiations, the next step would be mediation. The particular form of the proposed mechanism will need to be hybrid to maintain the flexibility needed. The particular mechanism employed in each case will vary and be regulated to minimize tensions and maximize effectiveness and protection of investment relationships. With discretion, harmony and legal creativity. It cannot be rigid or absolute. Both parties can thereby be able to claim a win within their governments and states.

61 ICC is a very successful example in this regard. To be more specific, ICC arbitration could settle both commercial and investor-state disputes between general corporations, stateowned enterprises, sovereign states and international organizations. 
Since there have already been various international dispute resolution institutes all over the world who keep innovating so as to provide more satisfying services, ${ }^{62}$ then why would relevant parties choose the Centre, if it would be established, instead of the more experienced ones, such as the Hong Kong International Arbitration Centre or the Singapore International Arbitration Centre? The Centre would act as a platform and registrar for such institutions. The long-term accumulated experiences of the ICSID, the ECT and the CEDR could provide some insight. ${ }^{63}$

ICSID and CEDR seem to share more common perspectives, compared with the ЕСт. Usually relevant parties would consider the quality and acceptability of the award, impartiality and predictability of the application of law, whether the procedure is easy to follow, the reputation of the institute and the administrative fees. As noted by CEDR, location of such a platform is vitally important for the parties in dispute. Furthermore, candidate list of neutrals also plays a critical role in terms of experience, qualification and credentialing. In comparison, the ECT chose to consider two factors which could affect choices between different providers, naming impartiality and predictability of the application of law and location of the institute.

When selecting the neutral, parties pay attention to different aspects. Put differently, it depends on what type of selection procedure is chosen. For arbitration, for example, the candidate's acquired technical expertise and knowledge in a particular subject matter and on particular legal views on certain issues play a pivotal role. With regard to mediation, proper training and recognized credentialing, process expertise, subject matter expertise, familiarity with the issues in dispute and cultural background are more important.

With respect to recognition and enforcement of the mediation agreement properly, during the process of accepting a new member to the Centre, relevant parties could be required to acknowledge that any final decision, award or judgment made by the Centre shall be recognized as the final decision made by their local judicial platform. Nevertheless, the contracting party could

62 For example, the ICSID unveiled a working paper to propose changes to the Rules, including but not limited to 1. reducing time and cost in proceedings; 2. introducing enhanced transparency rules, including a disclosure of third-party funding obligation and special rules on security for costs; 3 . revising process for the disqualification of arbitrators, and 4 . expanding access to the Additional Facility.

63 Please note subsection 4.2 was based on survey feedback of one working staff from each of the ICSID, the ECT and the CEDR on China and BRI dispute resolution. It is a limited summary of their personal views and their respective experiences. They are informal and preliminary questions about factors which influence a party's choice of a dispute resolution institutions. 
record reservations with regard to this provision when joining the Centre. The UN Convention on International Settlement Agreements Resulting from Mediation will be signed on 7 August 2019 in Singapore, two days before country's bicentennial National Day. The Singapore Convention could serve as an enforcement mechanism for international mediated settlement agreements.

\section{$5 \quad$ Conclusion}

The regionalism versus internationalism debate has given rise to a rich debate in the field of international trade law. There are those that view regionalism as a way to promote international integration, while the others view regionalism as 'protecting' regions and thus against the multilateral spirit that characterizes a truly global organization. This has ramifications these days in the light of Brexit and the regional trade agreement that the EU has provided to the UK (single market and customs union), which the UK wishes to exit. But it also reverberates in emerging economies preferential agreements and the 'graduation' issues present challenges for development. The debate is now also explored in international finance and investment by international financial institutions, including the АІІв, which has to be taken out of the dilemma of a 'regional threat' versus 'opportunity' depending on the view point involved. What is argued here is that principled dispute regulation will provide a new dimension to underpin regionalism within global governance. This debate would ultimately result in an intellectual anchor for the rule of law within multilevel governance.

This is not the end. It is not even the beginning of the end of the debate. Ever since it was put forward for the first time in 2013, the BRI has attracted attention all over the world. What the exponents of the BRI seem to want to achieve is more than a free trade area but less than a common market. Through providing an open, inclusive and balanced investment and trade cooperation platform, the BRI aims to achieve a community of common destiny. During the construction process, investment, commercial or trade disputes between individuals, undertakings, institutes, authorities and countries cannot be avoided. However, there is no simple dispute resolution mechanism that could efficiently resolve the above-mentioned conflicts. On the basis of existing wellestablished mechanisms, this chapter argued that a permanent, institutionalized and comprehensive dispute resolution system could be set up, affiliated with the AIIB, and well geared to resolve a variety of conflicts, at least in the not too distant future. Nevertheless, due to the particular political and social environments in some B\&R Participating States, a flexible method could be 
adopted. We specifically proposed the establishment of consultation as the pre-condition for initiating a case before the Centre. Among the range of possible methods to regulate disputes, mediation was recommended as presenting critical advantages in the context of the BRI and the B\&R Participating States-with their tremendous diversity, sensitivities and peculiar political and legal complexities. When considering that China will remain the driver and engine behind the вRI, nothing could contribute more to the traditional perception of Chinese 'harmony' than smart, fair and efficient negotiation mechanisms based on a solid mediation platform. This will allow for the efficient resolution of disputes that arise along the $B \& R$ and will not jeopardize the long and promising road ahead.

\section{Reference List}

AIIB, AIIB Articles of Agreement (AOA), art1.

AIIB, Operational Policy on Financing (January 2016, updated March 21, 2017) <www .aiib.org/en/policies-strategies/_download/operation-policy/policy_operational _financing_new.pdf $>$ accessed 30 December 2018.

AIIB, 'AIIB Receives Third Triple-A Credit Rating' (AIIB 18 July 2017) <www.aiib.org/ en/news-events/news/2017/20170718_oo1.html > accessed 30 December 2018.

AIIB, 'Members and Prospective Members of the Bank' (AIIB 28 December 2018) $<$ www.aiib.org/en/about-aiib/governance/members-of-bank/index.html > accessed 30 December 2018.

AIIB, 'Approved Projects' (AIIB) <www.aiib.org/en/projects/approved/index.html> accessed 30 December 2018.

Belt and Road Portal, 'Achievement Already Made by the AIIB Makes the Chinese Proud After Having Operated for Two Years' (Belt and Road Portal 17 January 2018) $<$ www.yidaiyilu.gov.cn/xwzx/pdjdt/44477.htm> accessed 30 December 2018.

Case C-284/16 Slowakische Republik v Achmea BV. [2018] ECLI:EU:C:2018:158, paras 57-59.

Duran C V, 'Voice and exit: How emerging powers are promoting institutional changes in the international monetary system' (2018) 15 Brazilian Journal of International Law 71.

Economic Information Daily, 'Conference on Interaction and Confidence-Building Measures in Asia Promotes Asian Economy Integration' China News (Beijing, 22 May 2014) <www.chinanews.com/cj/2014/05-22/6198502.shtml> accessed 30 December 2018.

Energy Charter Secretariat, 'Guidance on Investment Mediation', (Energy Charter Conference, Brussels, 19 July 2016). 
European Commission, 'Factsheet on Investor-State Dispute Settlement' (European Commission 3 October 2013) <http ://rade.ec.europa.eu/doclib/docs/2013/october/ tradoc_151791.pdf > accessed 29 December 2018.

European Commission, 'The Multilateral Investment Court Project' (European Commission 21 December 2016) <http://trade.ec.europa.eu/doclib/press/index.cfm? $\mathrm{id}=1608>$ accessed 30 December 2018.

Hirschman A O, Exit, Voice and Loyalty: Responses to Decline in Firms, Organizations and States (Harvard University Press 1990).

ICSID, 'Investor-State Mediation' (ICSID) < https://icsid.worldbank.org/en/Pages/ process/adr-mechanisms--mediation.aspx $>$ accessed 30 December 2018.

IBA Rules for Investor-State Mediation (4 October 2012).

Jin L, 'The AIIB's Investment in Infrastructure has to Meet Three Conditions' (v.ifeng. com 16 January 2018) <http://v.ifeng.com/video_11207554.shtml> accessed 30 December 2018.

Joerges C and Petersmann E, Constitutionalism, Multilevel Trade Governance and Social Regulation (Hart Publishing 2006).

Lee J and Hwee T (eds) An Asian Perspective on Mediation (Academy Publishing 2009).

Lichtenstein N, A Comparative Guide to the Asian Infrastructure Investment Bank (Oxford University Press 2018).

Lichtenstein N, 'Governance of the Asian Infrastructure Investment Bank in Comparative Context' (2018) AIIB Yearbook of International Law: Good Governance and Modern International Financial Institutions 56 .

MFA, 'Treaty Database of the PRC' <http://treaty.mfa.gov.cn/Treaty/web/index.jsp> accessed 30 December 2018.

Micklethwait J, Talev T and Jacobs J, 'Trump Threatens to Pull U.S. Out of WTO If It Doesn't "Shape Up"' (Bloomberg 30 August 2018) <www.bloomberg.com/news/ articles/2018-o8-3o/trump-says-he-will-pull-u-s-out-of-wto-if-they-don-t-shape -up?srnd=premium-europe $>$ accessed 30 December 2018.

Morris S, 'Responding to AIIB: U.S. Leadership at the Multilateral Development Banks in a New Era' (Centre for Global Development 2016) <www.cgdev.org/publication/ responding-aiib-us-leadership-multilateral-development-banks-new-era > accessed 20 February 2019.

Nagpal R, 'Dispute Resolution in Development Finance: The Perspective of the Asian Development Bank' (2018 AIIB Legal Conference, Beijing, September 2018).

Petersmann E, 'The 2018 American and Chinese trade wars risk undermining the world trading system and constitutional democracies' (2018) 2018/17 EUI Department of Law Research Paper <https://papers.ssrn.com/sol3/papers.cfm?abstract _id=3275188 $>$ accessed 20 February 2019.

Qiu S and Beijing Monitoring Desk, 'China-led AIIB approves 13 new members, Canada joins' (Reuters 23 March 2017) <www.reuters.com/article/us-china-aiib/china 
-led-aiib-approves-13-new-members-canada-joins-idUSKBN16UoCG> accessed 30 December 2018.

Queen Mary University of London and White \& Case LLP., 2015 International Arbitration Survey: Improvements and Innovations in International Arbitration (White \& Case 2015) <www.arbitration.qmul.ac.uk/media/arbitration/docs/2015_Interna tional_Arbitration_Survey.pdf $>$ accessed 29 December 2018.

ShamirY and Kutner R, 'Alternative Dispute Resolution Approaches and Their Application' (UNESCO's International Hydrological Programme to the World Water Assessment Programme 2003) <https://unesdoc.unesco.org/ark:/48223/pfoooo133287> accessed 20 February 2019.

Sirilal R, 'Chinese firm pays $\$ 584$ million in Sri Lanka port debt-to-equity deal' (Reuters 20 June 2018) <www.reuters.com/article/us-sri-lanka-china-ports/chinese-firmpays-584-million-in-sri-lanka-port-debt-to-equity-deal-idUSKBN1JG2Z6 > accessed 29 December 2018.

The MDB Working Group on Infrastructure, 'Multilateral Development Banks Working Group on Infrastructure, Infrastructure Action Plan' (World Bank 2011) <http:// documents.worldbank.org/curated/en/828751468331900533/pdf/655610BRovioSeo OfficialoUseoOnlyogo.pdf > accessed 28 December 2018.

The National Development and Reform Commission (NDRC), the Ministry of Foreign Affairs (MFA) and the Ministry of Commerce (MOFCOM), 'Vision and Action to Promote the Co-Construction of a "Silk Road Economic Belt" and a “21st-Century Maritime Silk Road" (MOFCOM 30 March 2015) <http://zhs.mof com.gov.cn/article/xxfb/201503/ 20150300926644.shtml> accessed 29 December 2018.

The Supreme People's Court of the PRC, 'The Decision on the Establishment of International Commercial Expert Commission of the Supreme People's Court' (SPC 24 August 2018) <http://cicc.court.gov.cn/html/1/219/208/210/989.html> accessed 5 January 2019.

The Supreme People's Court of the PRC, 'The SPC Releases Matching Documents for the BRI International Commercial Dispute Resolution Mechanism, Promoting the Establishment of "One-Stop-Shop" International Commercial Dispute Mechanism Resolution Platform' (SPC 5 December 2018) < www.court.gov.cn/zixun-xiang qing-134291.html> accessed 30 December 2018.

United Nations Conference on Trade and Development, World Investment Report 2018: Investment and New Industrial Policies (United Nations 2018) <https://unc tad.org/en/PublicationsLibrary/wir2018_en.pdf> accessed 29 December 2018.

Ury W, Brett J M and Goldberg S B, Getting Dispute Resolved: Designing Systems to Cut the Costs of Conflict (Jossey-bass 1993).

Wang G, 'The Belt and Road Initiative in Quest for a Dispute Resolution Mechanism' (2017) 25 Asia Pacific Law Review 1. 
Wang L, 'The Short-to-Middle-Term Goals of the BRI are Being Implemented' (International Financial News 28 June 2016) <http://finance.sina.com.cn/roll/2016-o6-28/ doc-ifxtmses1335020.shtml > accessed 28 January 2019.

Watt N, Lewis P and Branigan T, 'US Anger at Britain Joining Chinese-Led Investment Bank AIIB' The Guardian (London, 13 March 2015) <www.theguardian.com/us -news $/ 2015 / \mathrm{mar} / 13 /$ white-house-pointedly-asks-uk-to-use-its-voice-as-part-of-chi nese-led-bank $>$ accessed 30 December 2018.

WTO, 'Appellate Body appointments' (WTO, 22 June 2018) <www.wto.org/english/ news_e/news18_e/dsb_22jun18_e.htm $>$ accessed 30 December 2018.

Xiang H, 'List of Civil and Criminal Judicial Assistance Treaties (Already) Signed by the P.R.C'. (npc.gov.cn, 8 December 2017) <www.npc.gov.cn/npc/lfzt/rlyw/2017-12/24/ content_2034951.htm $>$ accessed 28 January 2019.

Xinhua Net, 'President Xi Jinping, 'Jointly Promote Establishment of the BRI” (Xinhua Net 14 May 2017) <www.yidaiyilu.gov.cn/xwzX/xgcdt/13208.htm > accessed 22 February 2019 .

Xinhua Net, 'What are the Participating Countries Along the Belt and Road' (Xinhua Silk Road Information Service 25 December 2017) <http://silkroad.news .cn/2017/1225/76186.shtml> accessed 28 January 2019.

Xinhua Net, 'The All-round and Deep Reform Leading Team Deliberates and Passes "Opinions on Establishing the BRI Dispute Resolution Mechanism and Institute" (Belt and Road Portal 24 January 2018) <www.yidaiyilu.gov.cn/xwzx/xgcdt/45583 .htm $>$ accessed 30 December 2018.

Xinhua Net, 'China proposes an Asian infrastructure investment bank' China Daily (Beijing, 3 October 2013) <www.chinadaily.com.cn/china/2013-10/03/content_17007977 .htm $>$ accessed 30 December 2018.

Xinhua Net, 'President Xi Jinping Meets with the Current Chairman and the Chairman to be of the Boao Forum for Asia' (Xinhua Net 11 April 2018) <www.xinhuanet.com/ fortune/2018-04/11/c_1122668091.htm > accessed 22 February 2019.

Zeng L, 'Conceptual Analysis of China's Belt and Road Initiative: A Road towards a Regional Community of Common Destiny' (2016) 15 Chinese Journal of International Law 517 .

Zhang L and others, 'China's High Savings: Drivers, Prospects, and Policies' (International Monetary Fund 11 December 2018) <www.imf.org/en/Publications/WP/ Issues/2018/12/11/Chinas-High-Savings-Drivers-Prospects-and-Policies-46437> accessed 28 January 2019. 